\title{
ARCHITECTURAL CHARACTERISTICS STUDY ON COMMUNITY MOSQUES IN PRIANGAN 1900 - 1942
}

Esti Istiqomah

Bambang Setia Budi

\author{
Program Studi Arsitektur ITB \\ Bandung, Jawa Barat, Indonesia \\ e-mail: joeymeeko@yahoo.com
}

Program Studi Arsitektur ITB

Bandung, Jawa Barat, Indonesia

e-mail: bambang@ar.itb.ac.id

\begin{abstract}
Priangan was a region with a distinctive historical background and administrative unity. The region consisted of 7 regencies in present West Java Province. There were some old community mosques in the region. The aim of this paper is to formulate architectural characteristics of Priangan old community mosques and their overall development. The mosques are no longer observable today. Therefore, the study is referring to old documentations. The oldest available documentations of such mosques were presented in the form of photos from Dutch colonial era, after the ethical policy. Therefore, the study is limited from the year 1900 to 1942. Based on the photos, the mosques were resketched by outlining the intended variables, which are building mass, transitional space, and roof. There were some common architectural characteristics that can be concluded from Priangan old community mosques. The common characters are single mass, surrounding verandah, and two stacked pyramidal roof. On the overall development, the mosques showed the peak of architectural characteristics variations on the photos that were taken in the year 1925.
\end{abstract}

Keywords: mosque, Priangan, colonial, characteristic, architecture

\begin{abstract}
Abstrak
Priangan merupakan suatu wilayah yang memiliki kesamaan latar historis dan pernah memiliki kesatuan administrasi. Wilayah ini meliputi 7 kabupaten di Provinsi Jawa Barat saat ini. Di wilayah tersebut terdapat masjid-masjid komunitas lama. Makalah ini bertujuan untuk merumuskan karakteristik arsitektural masjidmasjid komunitas lama yang ada di Priangan serta kecenderungan perkembangan keseluruhannya. Masjidmasjid tersebut saat ini sudah tidak dapat diamati lagi di lapangan. Oleh karena itu, studi karakteristik dilakukan melalui sumber dokumentasi bersejarah. Dokumentasi masjid-masjid tersebut mulai muncul pada masa kolonial Belanda setelah politik etis dalam bentuk foto. Oleh karena itu, kurun waktu kajian dibatasi antara tahun 1900 hingga tahun 1942. Dari foto-foto tersebut, masjid kemudian di sketsa ulang untuk memperjelas variabel-variabel yang akan dianalisis, yaitu massa, ruang, dan atap. Dari hasil analisis, didapatkan karakteristik arsitektural masjid komunitas lama di Priangan yang umum, yaitu memiliki massa tunggal, selasar keliling, dan atap tumpang 2 tumpuk. Kemudian dalam foto masjid-masjid yang diambil tahun 1925, karakter arsitektural masjid menjadi semakin beragam.
\end{abstract}

Kata kunci: masjid, Priangan, kolonial, karakteristik, arsitektur

\section{Introduction}

Based on a preliminary study, Priangan had old community mosques which shared architectural characteristics similarities among them. Priangan was a region in West Java which had distinctive historical background and administrative unity. Priangan was one of the fractions of Sunda Pajajaran Kingdom. When Sunda Kingdom collapsed, it was divided into smaller fractions, among them were
Sumedanglarang and Galuh. Galuh was conquered by Mataram Islam Kingdom in 1595. Then Sumedanglarang surrendered to Mataram in $1620^{1}$. The area which had been belonged to Sumedanglarang and Galuh were then called Priangan ${ }^{2}$.

Since 1677, the domination over Priangan region was rendered from Mataram to VOC (Vereneeging Oost-Indische Compagnie), a monopoly holder Dutch trading company. It went bankrupt and 
was dissolved in 1799. Its assets were taken over by Dutch Government ${ }^{3}$, including Priangan. Priangan then came under a short period of British Colonial Government from 1811 - 1816 like the rest of Indonesian Archipelago. But from 1816, the Dutch Colonial Government regained its reign on the Archipelago, and kept its domination until being defeated by the Japanese in 1942 .

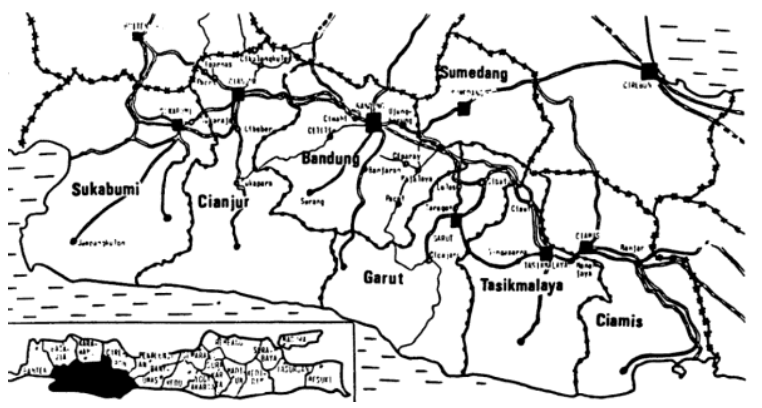

Picture 1. Seven Regencies of Priangan in 1925s (Source: Svensson, 1991)

Priangan's administrative borders were not all static, but underwent some changes throughout history. Nevertheless, Priangan area could be summed up in 7 regencies that are present in today's West Java Province. The regencies are Sukabumi, Cianjur, Bandung, Sumedang, Garut, Tasikmalaya, and Ciamis ${ }^{4}$.

The old community mosques in Priangan were no longer observable in the field. Therefore, the study will refer to old documentations. The accessible documentations of those mosques were started to be made around 1900. The Ethical Policy was also established around that time ${ }^{5}$. By that policy, Dutch Colonial Government paid more attention to the natives' welfare, such as education and health. Based on those reasons, the time frame of the study were limited from 1900 to 1942 when Dutch Colonial reign was ended by the Japanese invasion.

Bambang Setia Budi had classified old mosques under sultanates in Java into 4 categories based on their role and setting ${ }^{6}$. First category was the great mosque which was located in the heart of the city and became a symbol of the ruler's greatness. The second mosque was langgar kraton mosque which was located inside the palace (kraton) complex and especially used by the women in the palace. The third category was community mosque which was located among the society and used by them, such as kampung (village) mosque and pesantren (native's Islamic boarding school) mosque. The fourth category was isolated mosque which was located in inland areas, such as the mountains, and adjacent to graveyard.

The mosques in this study could be classified into the third category. Nevertheless, the above classification was made on mosques under sultanate, while Priangan was not a region in the form of sultanate. Therefore, there can be some characteristic differences between the mosques in the third category and the community mosques in Priangan. There were also some old great mosques in Priangan which were located on the capital regencies. Those mosques are not discussed further in this paper.

\section{Discussion}

\section{Research's Aim and Method}

The aim of the study is to formulate architectural characteristics of old community mosques in Priangan from 1900 to 1942 . The study encompasses the mosque as a whole mass to some more detail architectural elements. The tendency of community mosques' development from time to time will also be studied. Hopefully, this research will contribute to the knowledge of Islamic architecture diversity in Indonesian Archipelago.

This study is using historical research method from the qualitative method. The method has 4 systematic steps ${ }^{7}$. The first step is data searching. The second step is data criticizing. The third is findings interpretation. The fourth step is chronological writing of the findings. This method has it's concern on data's validity through data selection and critic.

Old community mosques in Priangan are no longer observable in present time. Therefore, the study will refer to the oldest available documentations of the mosques. The documentations are old photographs made around 1900 - 1942. The photos were acquired from the internet, mainly from KITLV (Koninklijk Instituut voor Taal-, Land-, en Volkenkunde) website and from Tropen Museum through Wikimedia.

There were 14 photos that were managed to be obtained which showed 10 different mosques. They were spread in 4 regencies, which are Sukabumi, Bandung, Garut, and Tasikmalaya. There was 1 mosque in Sukabumi. There were 2 mosques in Bandung, one in each Banjaran and Cibolang. In Garut there were 5 mosques, which were spread in Cisurupan, Tarogong, Cibatu, Garut City, and 1 other mosque that the specific location was not known. In Tasikmalaya, there were 2 mosques, which were located in Pamijahan and Singaparna. 
Table 1. Photographs of Community Mosques in Priangan 1900 - 1942

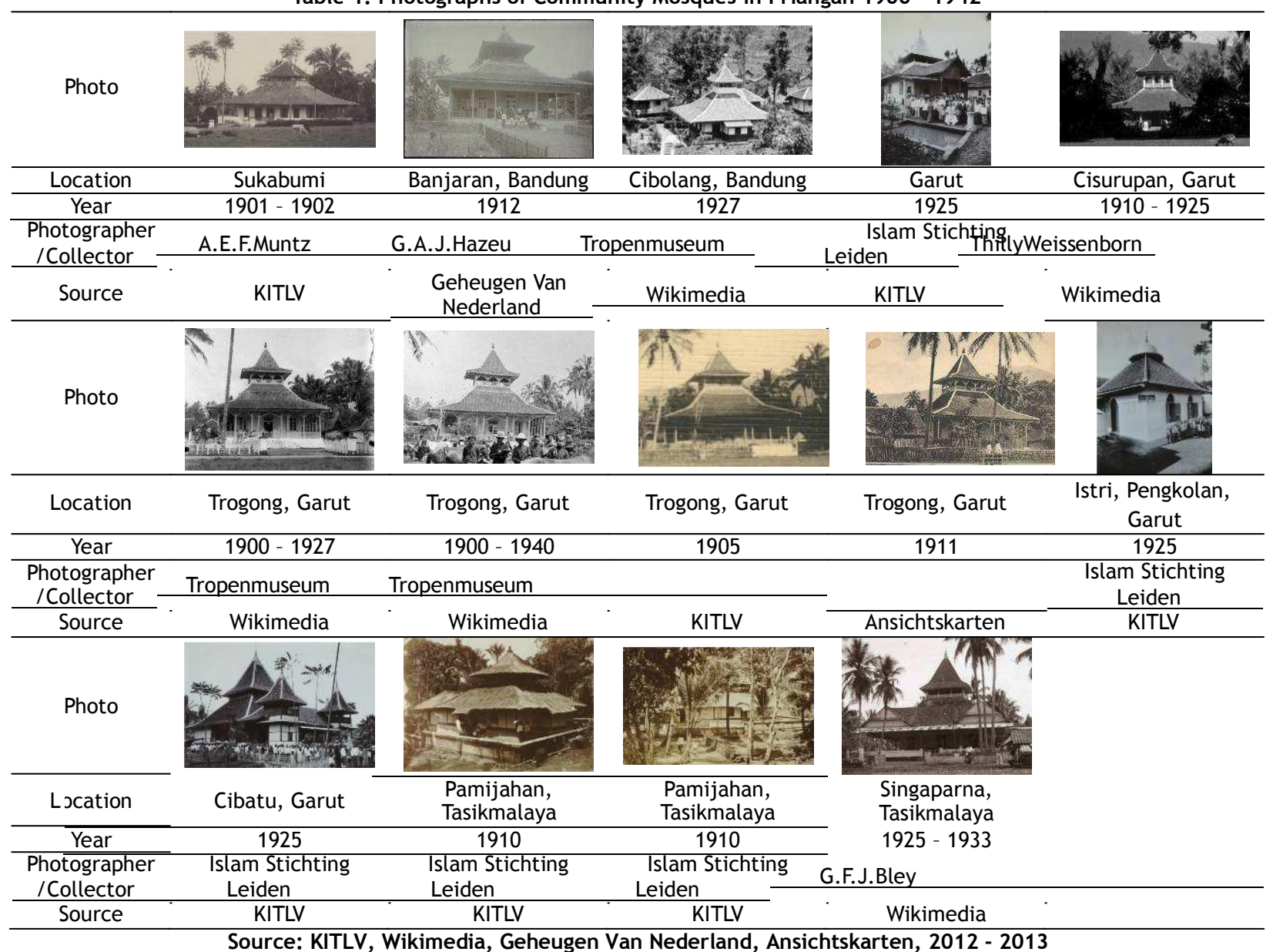

The mosques are then resketched based on their old photographs. Resketching was done by tracing the outline from the photos. Proposed outlines were also drawn for the lines of form that were not very clear or were could not be seen at all. It was done based on logical interpretation of form. The resketching was carried out to enhance the focus on certain variables or characteristics that were intended to be studied.

Literature studies that were conducted to determine the variables were about architectural characteristics and old mosques in Indonesian Archipelago. Sagsoz, Tuluk, and Ozgen $(2005)^{8}$ analyzed architectural characteristics from building's story height, symmetry, horizontal/vertical accent, overhang, entrance, bay window, and window. Those elements were seen from their position, dimension, form, and kind. There was also a study of Javanese old mosques by Bambang Setia Budi?. He stated that the mosques had square plan, pyramidal stacked roof, saka guru columns, surrounding wall, and located near graveyard complex. He also stated that minaret or tower and serambi (verandah) were additional features of the mosques that were not originated from them.
Architectural characteristics variables were then formulated based on those previous studies with some considerations about the limited information that can be gained from photos. The determined variables are mass, transitional space (verandah), and roof. The variables are seen from their kind, form, amount, position, and symmetry. The mosques are then compared by each variable. The development tendencies of the variables are also mapped out.

\section{Old Community Mosques in Priangan}

Based on the photos that were managed to be acquired for this paper, there were 10 old community mosques in Priangan.

\section{Mosque in Sukabumi (1901 - 1902)}

The mosque in Sukabumi was only consisted of the main mass. It had symmetrical mass. The mosque had verandah on the front and each side of its main room. The mosque had 2 stacked pyramidal roof with opening between the stacks which was divided into 3 modules by small columns. Each roof stack had 2 angles, steeper on the upper part and sloping more gently on the lower part. It also had ornated fascia board. 


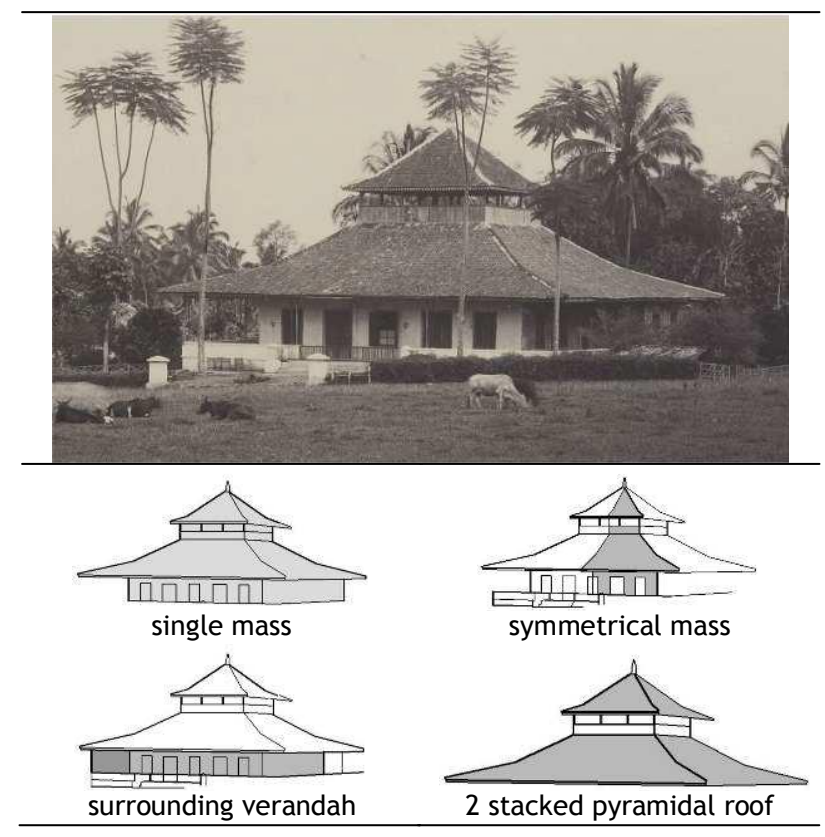

Picture 2. Mosque in Sukabumi (Source: KITLV, 2012)

2. Mosque in Banjaran, Bandung (1912)

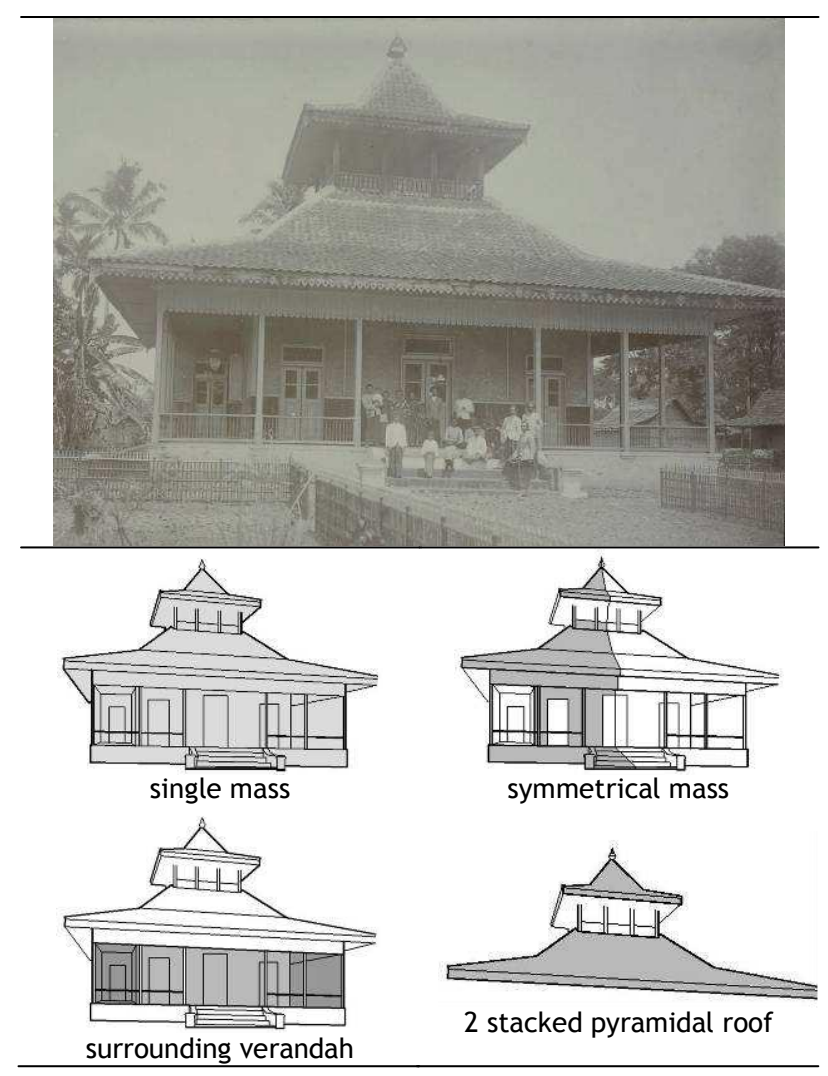

Picture 3. Mosque in Banjaran, Bandung (Source: Geheugen Van Nederland, 2012)

The Mosque in Banjaran, Bandung Regency, was only consisted of the main mass. It's mass was symmetrical. It's main room was surrounded by verandah in front and on each side of the room in 1 column module wide. The roof was 2 stacked pyramidal roof with opening between them was divided into 3 small modules. Both stacks had 2 sloping angles. The roof cover was tile roof. The roof had ornated fascia board and vertical planks ornament.

\section{Mosque in Cibolang, Bandung (1927)}

The Mosque in Cibolang was located in Assam tea plantation, Malabar, in Bandung Regency. The mosque was only consisted of the main mass. From the back side (Western view), the mosque appeared to have symmetrical mass. The main room was surrounded by verandah in front and on each side of the room. The roof was a 2 stacked pyramidal roof with opening between the stacks. Both stacks had 2 sloping angles.

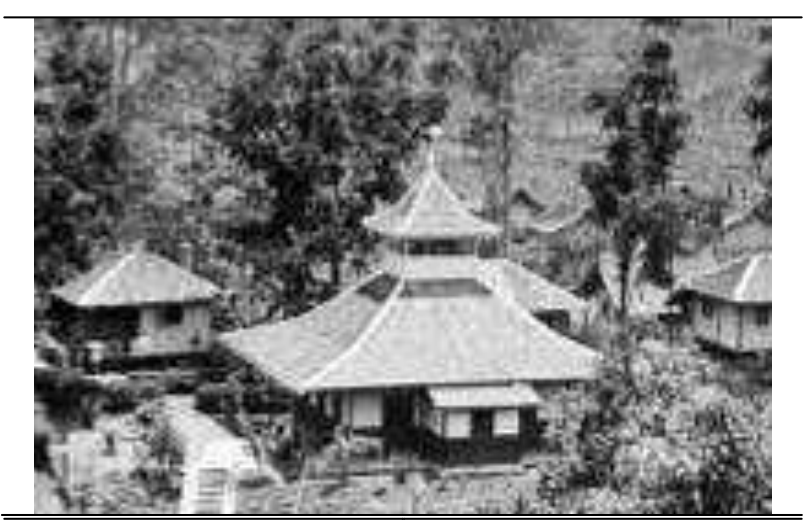

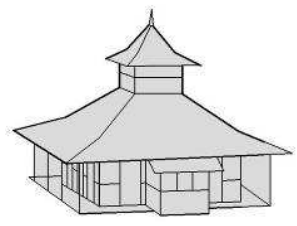

single mass

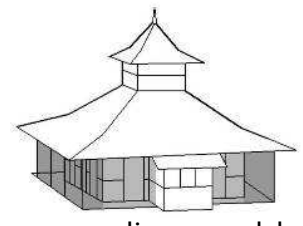

surrounding verandah

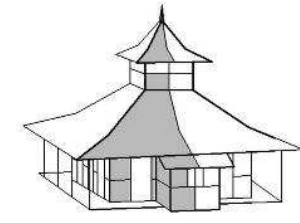

symmetrical mass

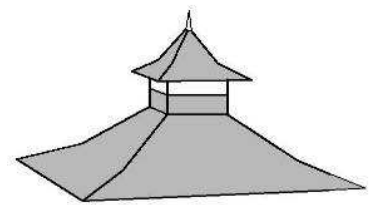

2 stacked pyramidal roof
Picture 4. Mosque in Cibolang, Bandung (Source: Wikimedia, 2013)

4. Mosque in Garut (1925)

The Mosque in Garut Regency, with unknown specific location, was only consisted of the main mass. The mosque had symmetrical mass. It only had terrace on the front side of the main room. The mosque's roof was consisted of the main and the additional part. The main roof was 2 stacked pyramidal roof with opening that was divided into 2 modules by small columns. The upper stack had 2 sloping angles. The lower stack was covered by tile 
roof. The additional roof was located in front and covered also by tiles. It had the form of gable roof connected with the extention of the main roof. There were also ornated vertical planks below the gable roof.

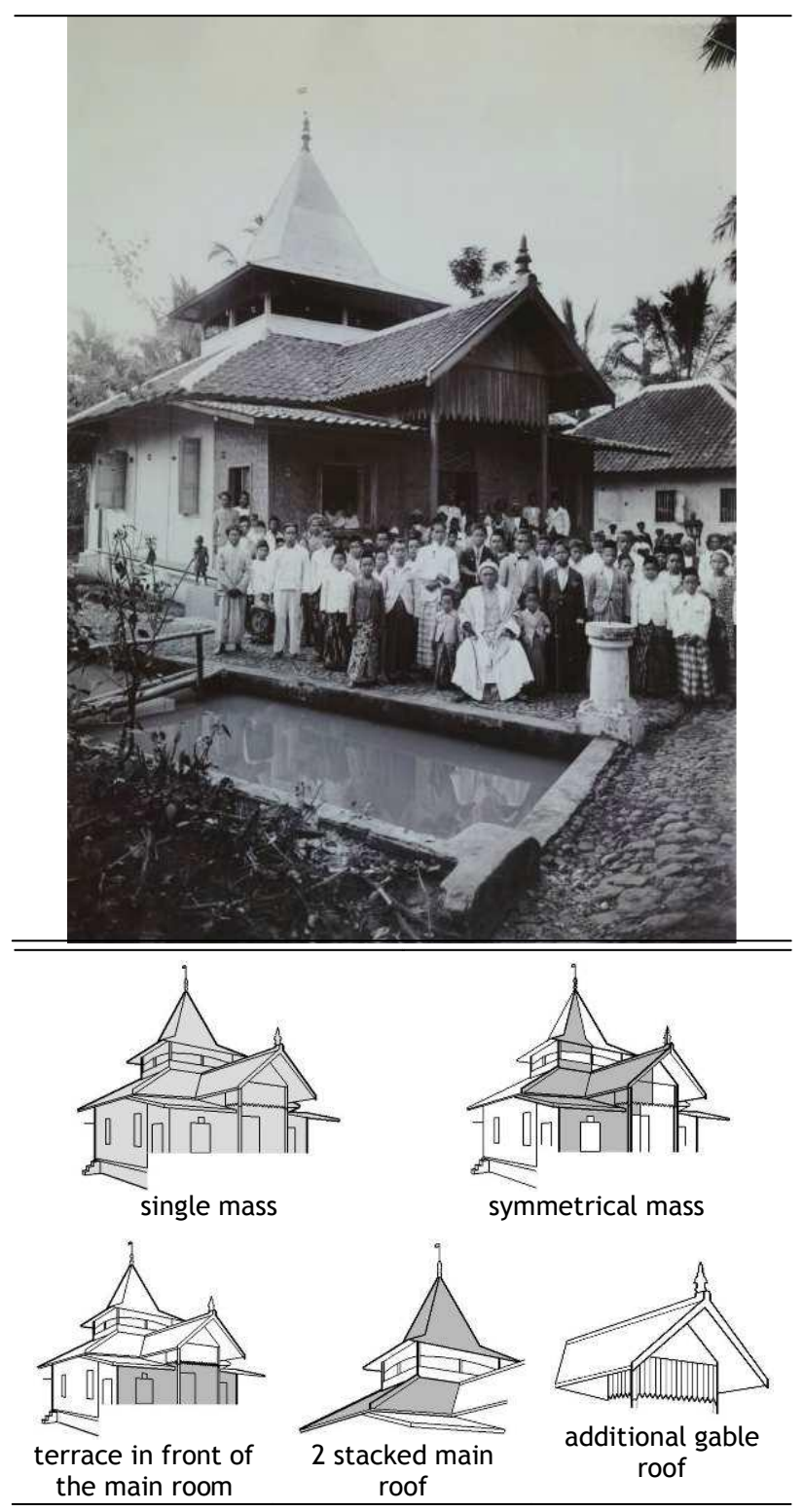

Picture 5. Mosque in Garut (Source: KITLV, 2012)

5. Mosque in Cisurupan, Garut (1910 - 1925)

The Mosque in Cisurupan, Garut Regency, was only visible by the roof part from the available photo. The main roof appeared to have no addition. It had symmetrical form. It was 2 stacked pyramidal roof with opening between them which was divided into 3 modules. Both stacks had 2 sloping angles.
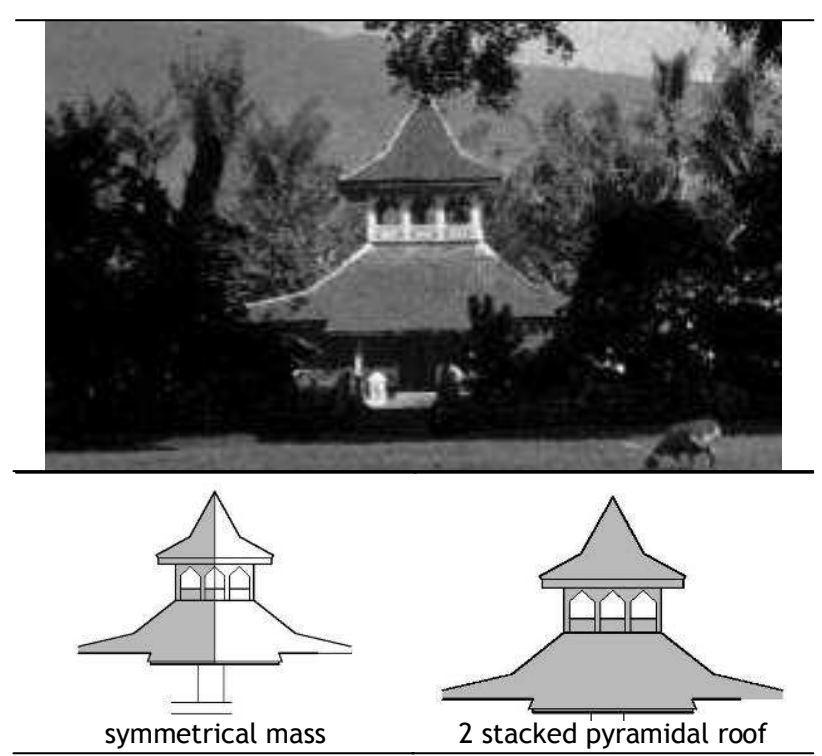

Picture 6. Mosque in Cisurupan, Garut (Source: Wikimedia, 2012)

6. Mosque in Tarogong, Garut (1905)

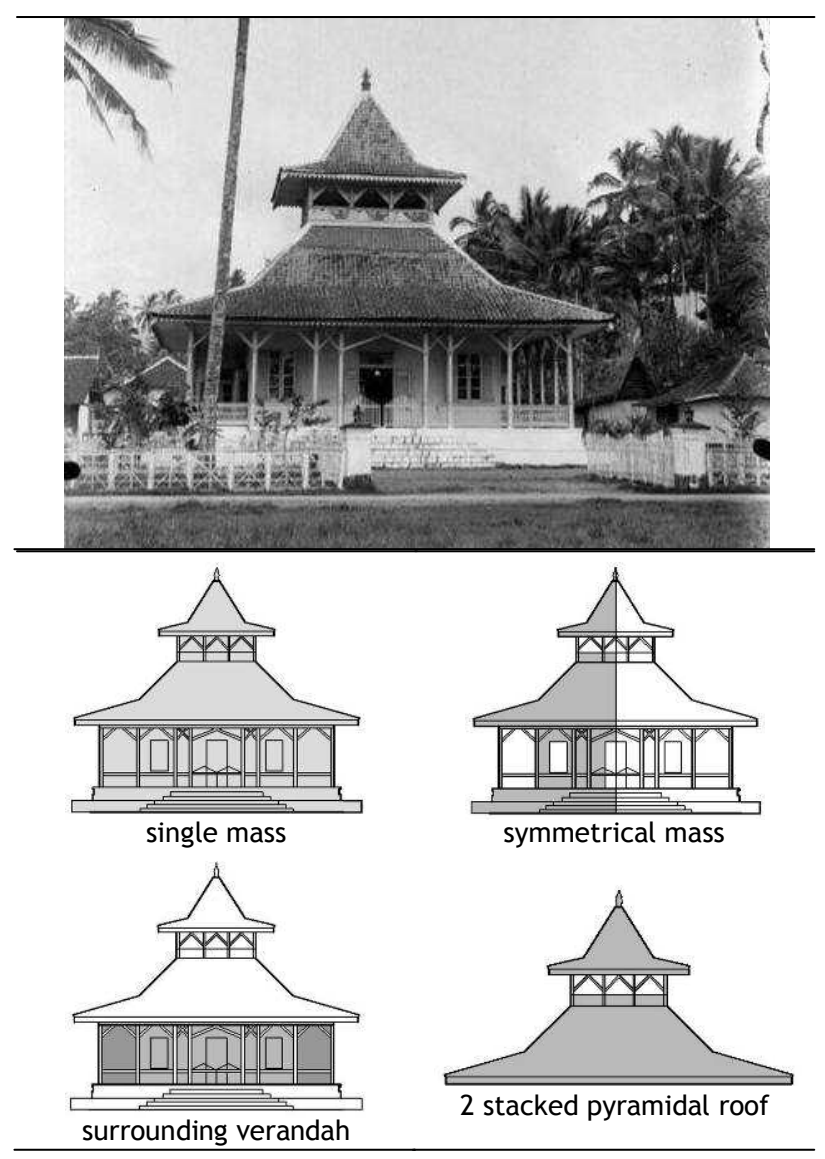

Picture 7. Mosque in Tarogong, Garut (Source: Wikimedia, 2013)

Mosque in Tarogong, Garut Regency, was only consisted of the main mass. The mosque had symmetrical mass. The main room was surrounded 
by verandah in front and on each side of the room. The roof had the form of 2 stacked pyramidal roof with opening between them that was divided into 3 small column modules. Both stacks had 2 sloping angles. The roof was covered with tiles and had ornated fascia board.

\section{Istri (Women) Mosque, Pengkolan, Garut (1925)}

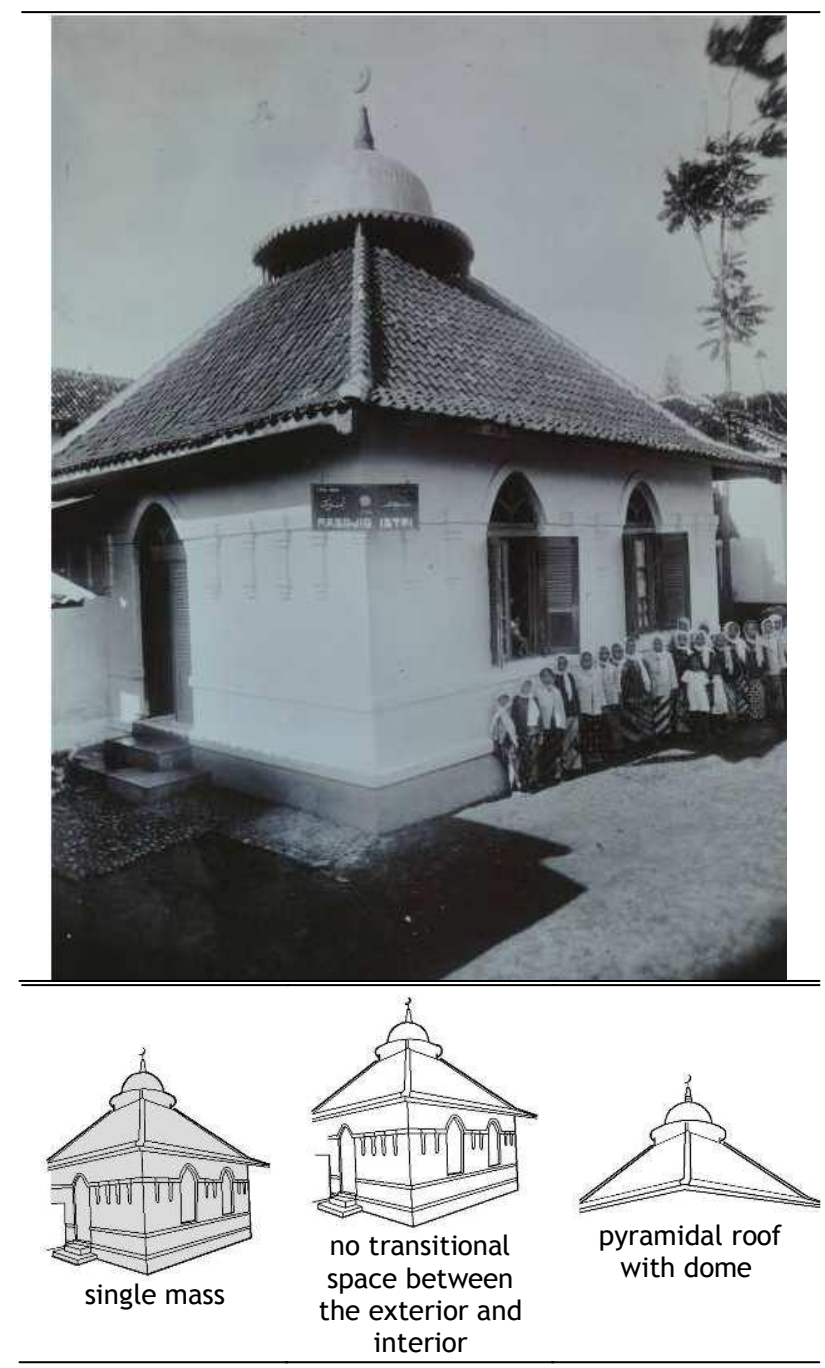

Picture 8. Istri Mosque, Pengkolan, Garut (Source: KITLV, 2012)

Istri Mosque in Pengkolan, Garut City, was consisted of the main mass. The front side (East view) of the mosque could not be identified from the photo. Therefore, the symmetricity of the mosque could not be determined. The mosque appeared to have no verandah or any transitional space between the exterior and interior. The mosque had pyramidal roof form with a dome on top of it. There was opening between the pyramidal roof and the dome. The pyramidal roof was covered with tiles and had 2 sloping angles.

\section{Mosque in Cibatu, Garut (1925)}

The Mosque in Cibatu, Garut Regency, was consisted of the main mass and additional masses. It had verandah in front of its main mass and twin towers on the side part. The additional masses were attached to the main mass and form a symmetrical configuration. These mass characteristics were also found on the great mosques in Priangan. The main room of Mosque in Cibatu had verandah on its both side. The mosque had 2 stacked pyramidal main roof with opening between the stacks. Verandah mass had hipped roof form. The twin towers had pointed roofs with openings below them. The roofs were all covered by tiles and had 2 sloping angles.

\section{Mosque in Pamijahan, Tasikmalaya (1910)}

The Mosque in Pamijahan, Tasikmalaya Regency, was consisted of the main mass and additional verandah mass in front. The masses were attached to each other and formed symmetrical configuration (seen from the back side of the mosque). The masses were surrounded by transitional space between the exterior and the interior which was formed by the space between the wall and the fence (trench-like space). The main roof had a 2 stacked pyramidal form with opening between the stacks. The upper stack had 2 sloping angles. The verandah's roof was a hipped roof. The roof cover was made from palm fiber.

10. Mosque in Singaparna, Tasikmalaya (1925 - 1933) The Mosque in Singaparna, Tasikmalaya Regency, was consisted of the main mass and additional verandah mass in front. The masses were attached to each other and formed a symmetrical configuration. The main room was surrounded by verandah in front and on each side of it. The roof had a stacked pyramidal form with opening between the stacks which was divided into 3 modules. The upper stack had 2 sloping angles. Verandah's roof was hipped in form with the addition of twin gable form on it's sides. The verandah mass also had canopy extention for the roof.

\section{Architectural Characteristics Comparation of the Mosques}

1. Mass

From the available photos, old community mosques in Priangan can be divided into 2 major categories based on their masses. The first category was the mosques that only consisted of the main mass. Those mosques were in Sukabumi (1901 1902), Tarogong (1905), Cisurupan (1910 - 1925), Banjaran (1912), Garut (1925), Istri Mosque (1925), and in Cibolang (1927). Second category was the mosques which had additional mass. Those mosques were in Pamijahan (1910), Cibatu (1925), and 
Singaparna (1925 - 1933). The additional masses were verndah and minarets in Cibatu.

The conclusion for the mosque's mass characteristics can be summarized from table 2. All of the mosques were had symmetrical mass except for Istri Mosque that could not be determined due to its unknown mass orientation in the photo. Most of the mosques ( 7 from 10 ) were only consisted of the main mass. The mosques with mass addition started to appear from the 1910 photos. The rather distinguishable mosque was the Mosque in Cibatu which had twin towers, unlike any other mosques.

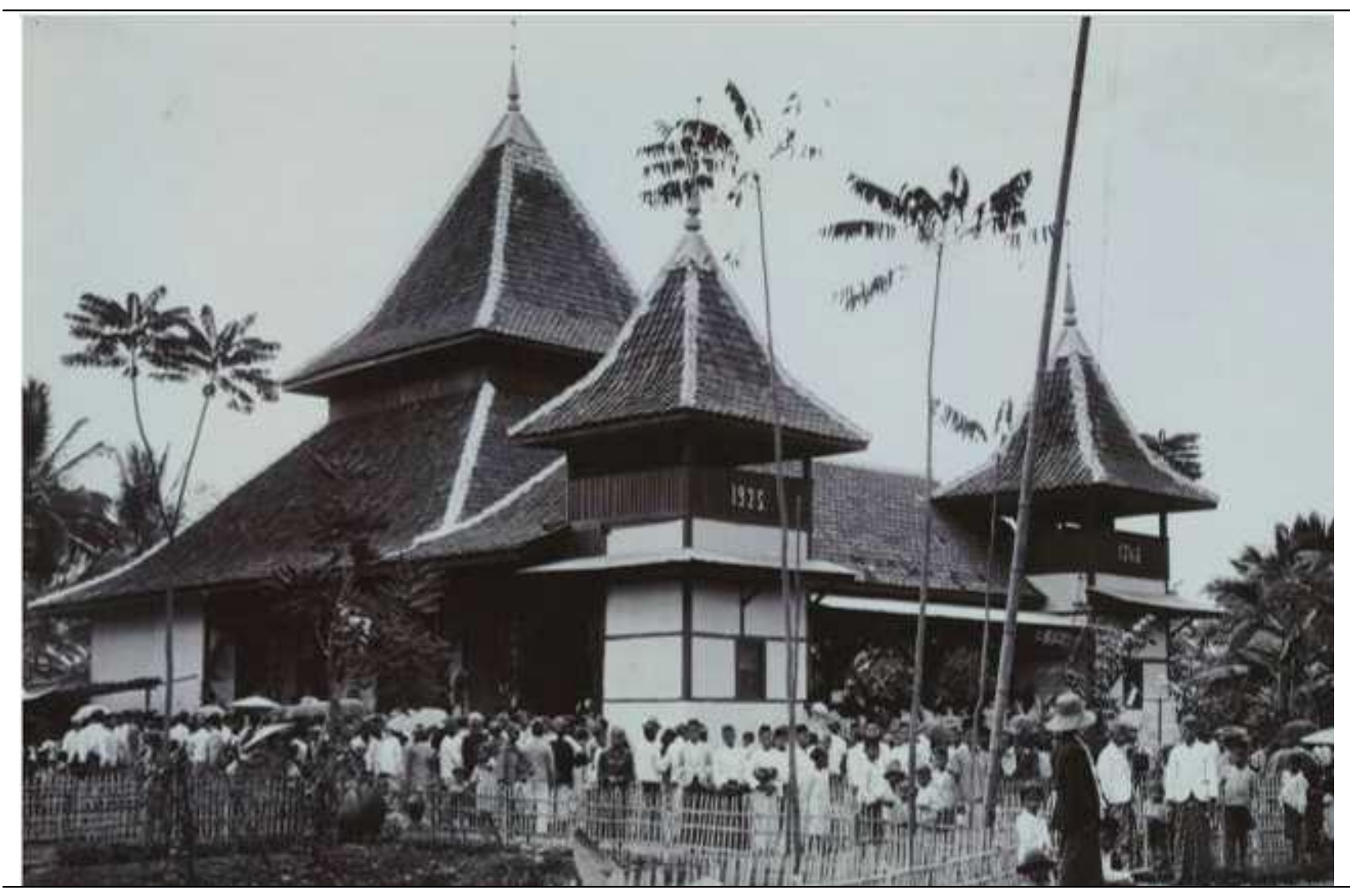

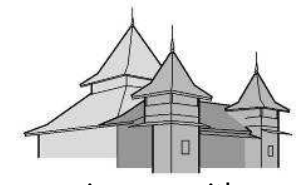

main mass with verandah in front and twin towers on it's sides

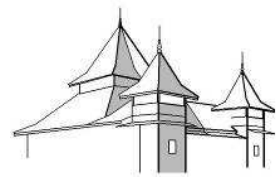

symmetrical mass

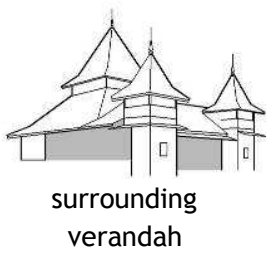

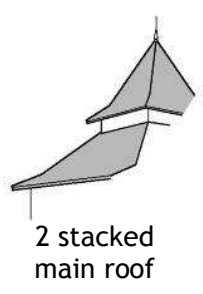

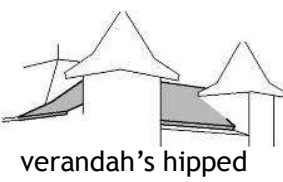
roof

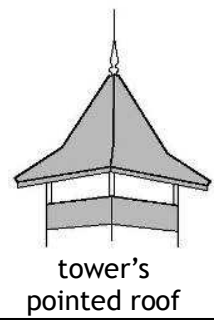

Picture 9. Mosque in Cibatu, Garut (Source: KITLV, 2012)

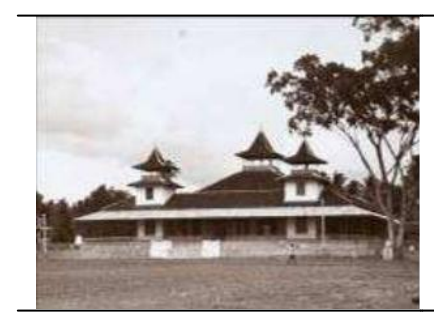

The Great Mosque of Cianjur $(1920$ - 1931)

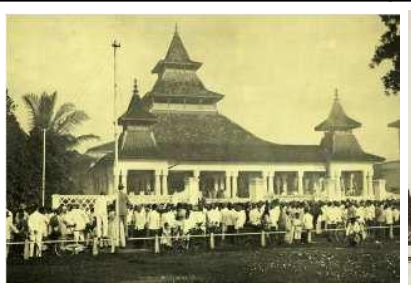

The Great Mosque of Bandung (1927)

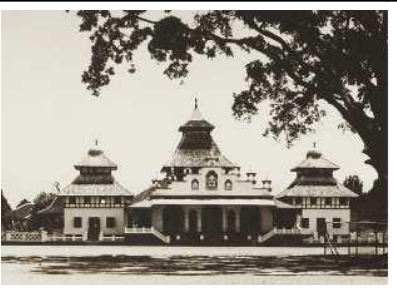

The Great Mosque of Garut (1925)

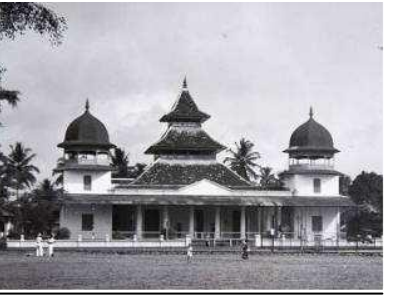

The Great Mosque of Tasikmalaya (1925 - 1933)

Picture 10. The Great Mosques in Priangan (Source: Wikimedia and KITLV, 2012 - 2013) 

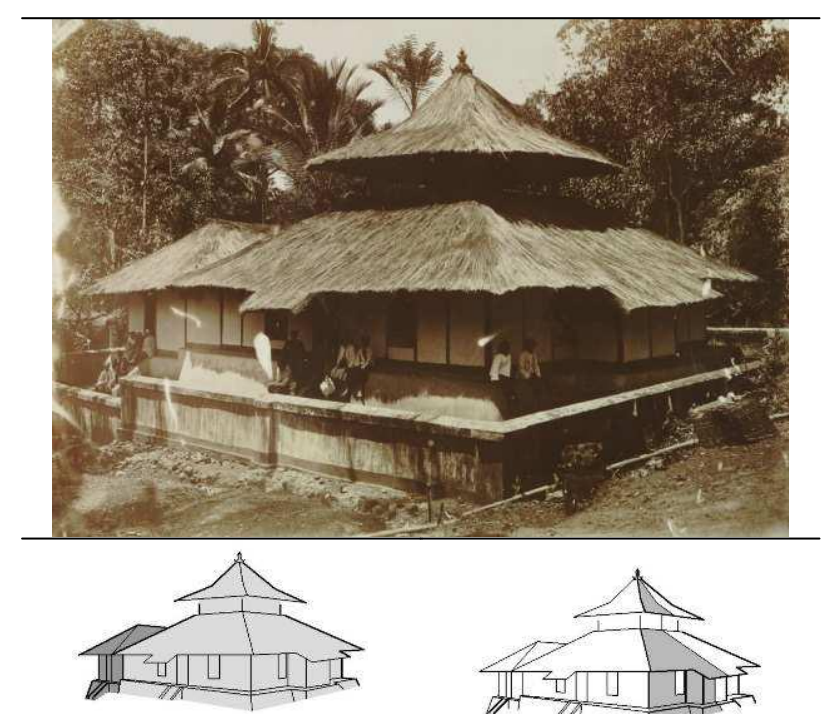

main mass with verandah mass in front
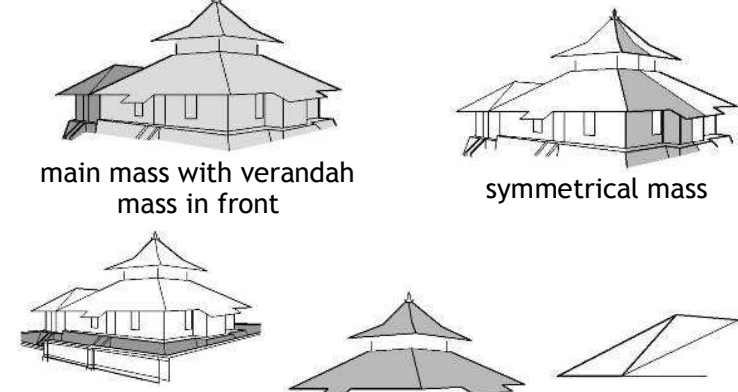

the masses were surrounded by exterior-interior transitional space

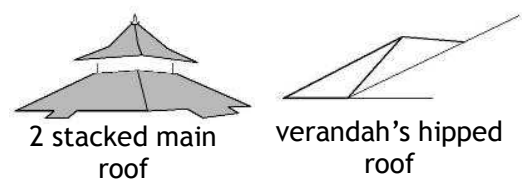

Picture 11. Mosque in Pamijahan, Tasikmalaya (Source: KITLV, 2012)

\section{Transitional Space (Verandah)}

From the photos, old community mosques in Priangan can be classified into 3 major categories based on their transitional space. The first category was the mosques which had transitional space between exterior and interior. Those mosques were in Sukabumi (1901 - 1902), Tarogong (1905), Pamijahan (1910), Banjaran (1912), and Cibolang (1927). The transitional spaces were in the form of verandah, except for the mosque in Pamijahan, which had it in the form of trench-like space. Second category was the mosques with extended verandah in front of the main room as additional mass. Those mosques were in Cibatu (1925) and Singaparna (1925 - 1933). Third category was the mosques that did not have transitional space surrounding the main room. Those mosques were in Garut (1925) and Istri Mosque (1925). Istri Mosque did not have any transitional space, while the Mosque in Garut only had the front terrace.

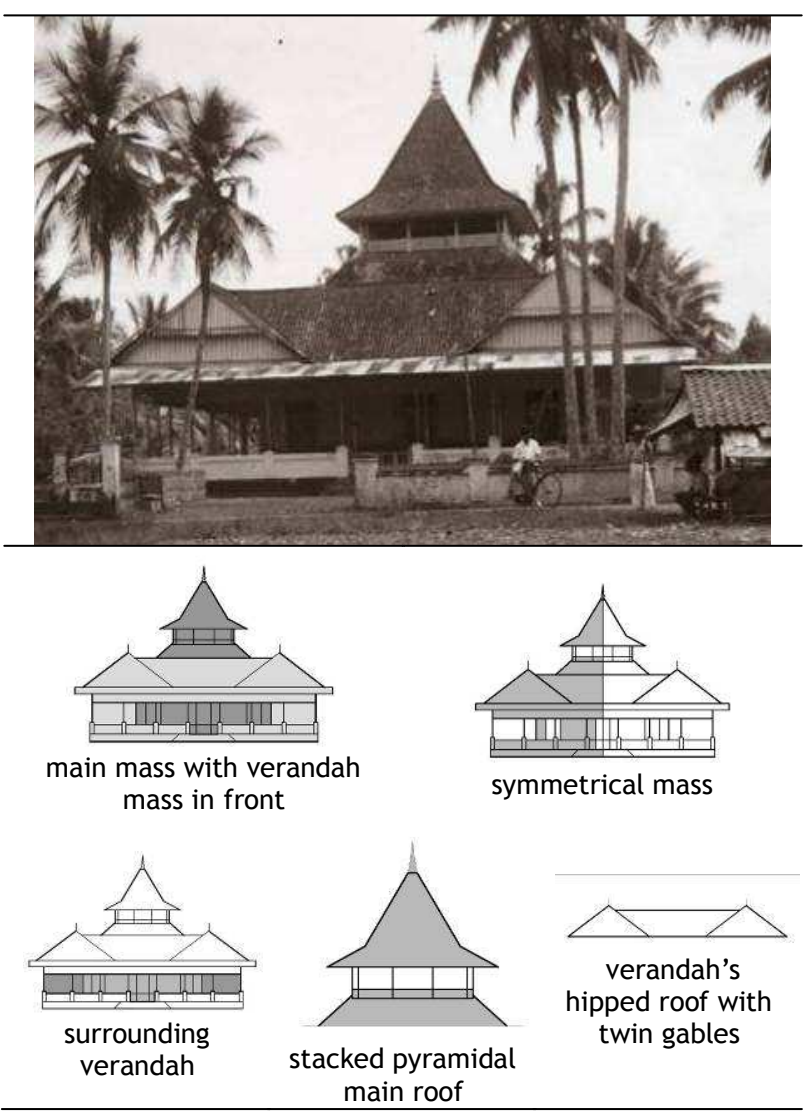

Picture 12. Mosque in Singaparna, Tasikmalaya (Source: Wikimedia, 2013) 
Table 2. Mass Characteristics of Community Mosques in Priangan

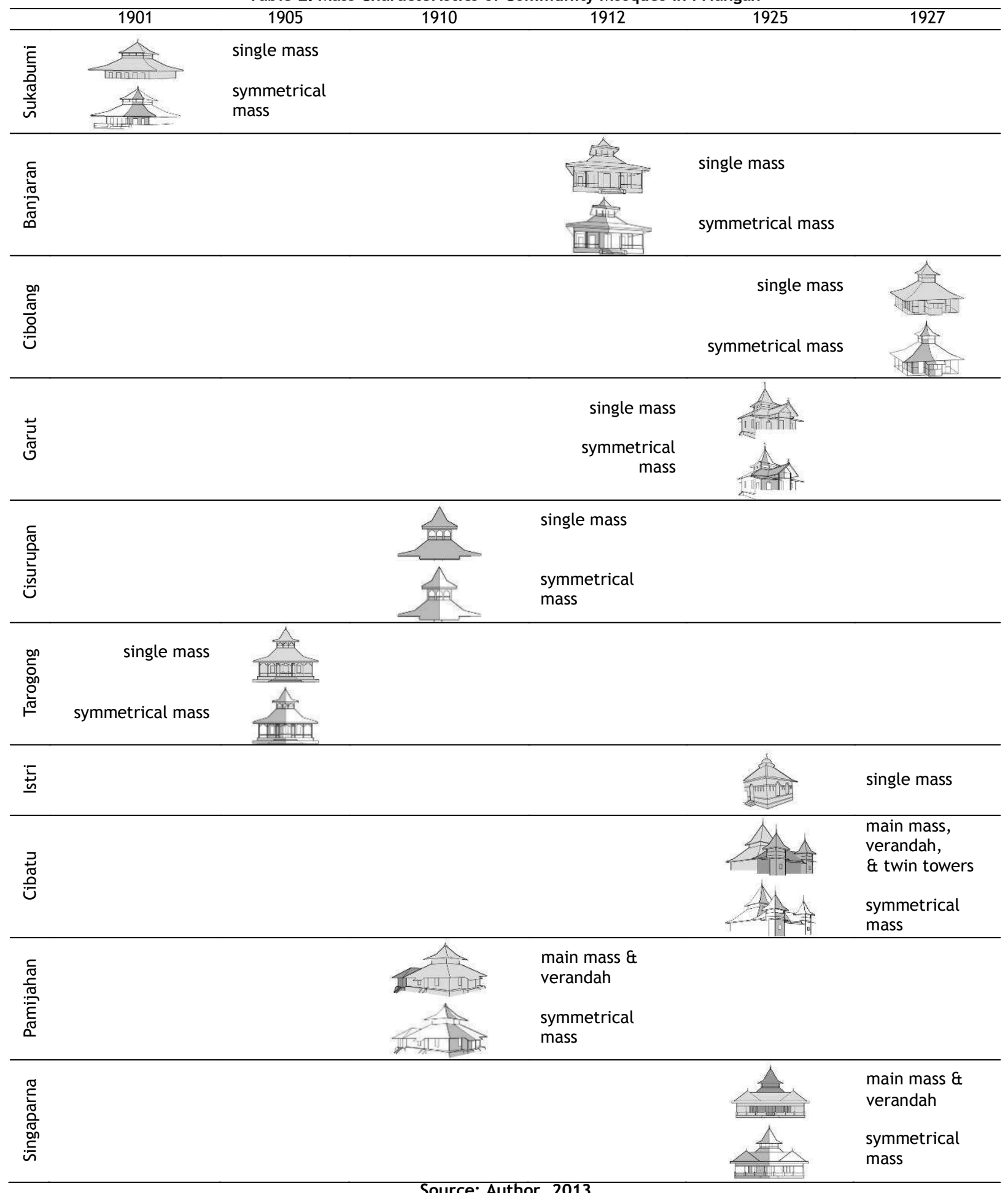


Table 3. Transitional Space Characteristics of Old Community Mosques in Priangan

\begin{tabular}{|c|c|c|c|c|c|c|}
\hline & 1901 & 1905 & 1910 & 1912 & 1925 & 1927 \\
\hline Sukabumi & Exमिए & $\begin{array}{l}\text { main room } \\
\text { was } \\
\text { surrounded } \\
\text { by verandah } \\
\end{array}$ & & & & \\
\hline Banjaran & & & & $\frac{\sqrt{\mathrm{A}+\mathrm{k}}}{\mathrm{n}}$ & $\begin{array}{l}\text { main room was } \\
\text { surrounded by } \\
\text { verandah }\end{array}$ & \\
\hline Cibolang & & & & 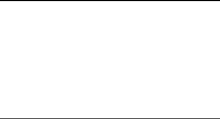 & $\begin{array}{r}\text { main room was } \\
\text { surrounded by } \\
\text { verandah }\end{array}$ & 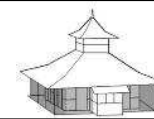 \\
\hline Garut & & & 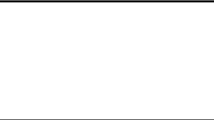 & $\begin{array}{r}\text { terrace in front } \\
\text { of the main } \\
\text { rooom }\end{array}$ & & \\
\hline \multicolumn{7}{|l|}{ Cisurupan } \\
\hline Tarogong & & लिखिए & $\begin{array}{l}\text { main room was } \\
\text { surrounded by } \\
\text { verandah }\end{array}$ & & & \\
\hline Istri & & & & & & $\begin{array}{l}\text { no } \\
\text { transitional } \\
\text { space }\end{array}$ \\
\hline Cibatu & & & & & & $\begin{array}{l}\text { extended } \\
\text { front } \\
\text { verandah } \\
\text { mass }\end{array}$ \\
\hline Pamijahan & & & 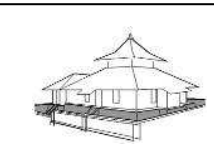 & $\begin{array}{l}\text { the masses } \\
\text { were } \\
\text { surrounded by } \\
\text { transitional } \\
\text { space }\end{array}$ & & \\
\hline Singaparna & & & & & Bमाप, & $\begin{array}{l}\text { extended } \\
\text { front } \\
\text { verandah } \\
\text { mass }\end{array}$ \\
\hline
\end{tabular}

Source: Author, 2013

Based on table 3, the transitional space characteristics on old community mosques in Priangan can be summarized. Most of the mosques $(8$ out of 10) had transitional space between the exterior and interior. Photos in the year 1925 showed the peak of variety for transitional space configurations. Photos from that year showed mosque with no transitional space to mosques with extended front verandah. The mosques with rather distinctive transitional space characteristics were Istri Mosque, the Mosque in Garut, and Pamijahan. Istri Mosque had no transitional space. The Mosque in Garut had only front terrace. The Mosque in Pamijahan had transitional space in trench-like form.

\section{Roof}

From the photos, old community mosques in Priangan can be classified into 2 major categories based on their roof. First category was the mosques which only had the main roof. Those mosques were in Sukabumi (1901), Tarogong (1905), Cisurupan (1910 - 1925), Banjaran (1912), Istri Mosque (1925), and in Cibolang (1927). Second category was the mosques which had additional roof. Those mosques were in Pamijahan (1910), Garut (1925), Cibatu (1925), and Singaparna (1925 - 1933). 
Table 4. Roof Characteristics of Old Community Mosques in Priangan

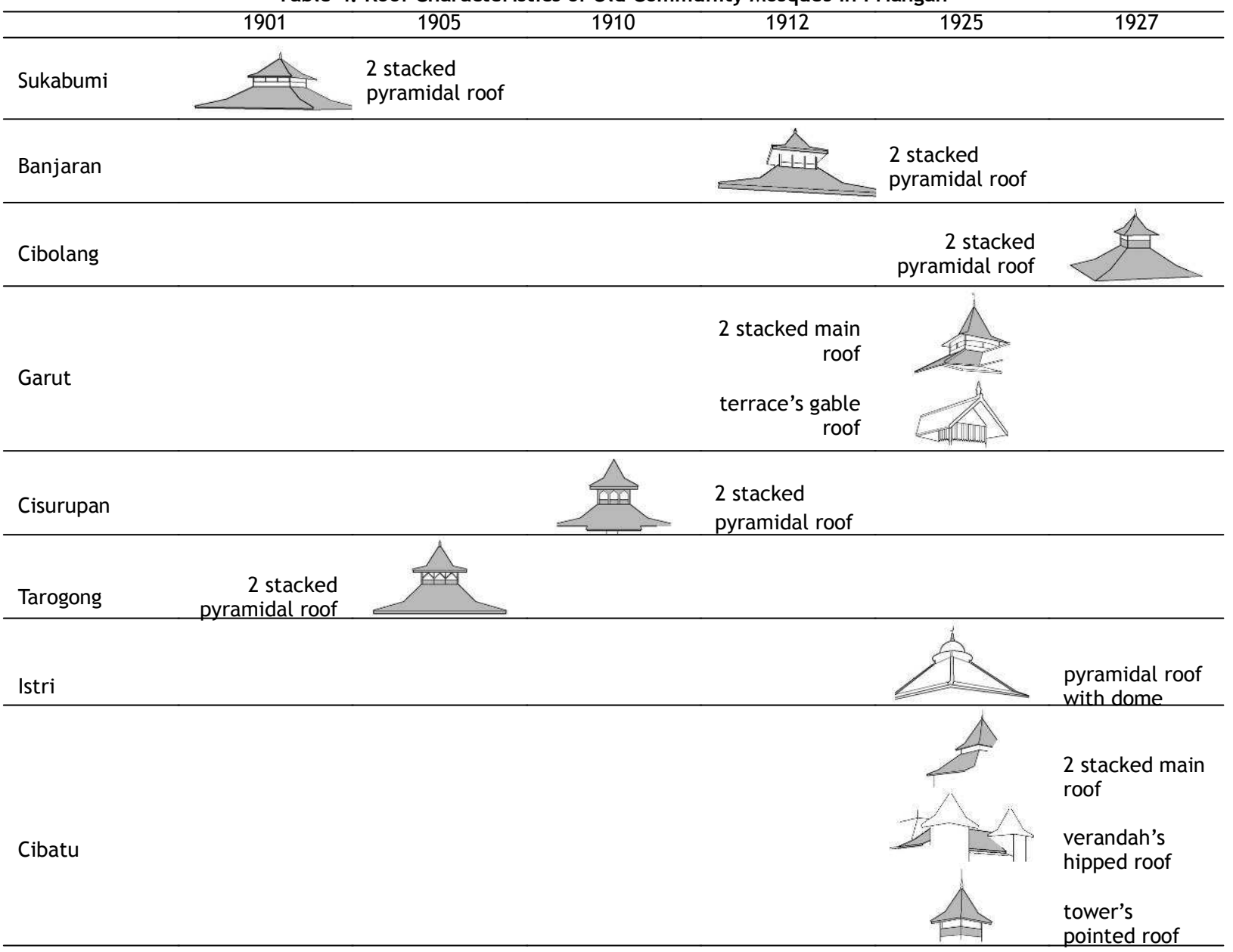

Singaparna

The mosque's main and additional roof shape also formed roof characteristics. All of the mosques had 2 stacked pyramidal main roof with opening between the stacks, except for Istri Mosque (1925) which had a dome instead on it's upper stack. All of the stacks had 2 sloping angles, except for the Mosque in Pamijahan (1910) and Garut (1925) which only had the 2 sloping on their upper stack. The additional roof forms were pointed, gable, and hipped roof. The pointed roofs which had 2 sloping angles were present at the towers of Mosque in Cibatu (1925). Gable roof was visible as terrace's roof of Mosque in Garut (1925). Hipped roofs were visible as verandah's roof on Mosque in Pamijahan (1910), Cibatu (1925), and Singaparna (1925 - 1933). The hipped roof on the Mosque in Pamijahan had 2 sloping angles. Hipped roof of Mosque in Singaparna had twin gables on it's sides.

Based on table 4, roof characteristics of old community mosques in Priangan can be summarized. All of the mosques had 2 stacked pyramidal main roof form, except for Istri Mosque. All of the mosques showed 2 sloping angles, either on both stacks or on one of the stacks. Additional roof was 
first seen in the photos from 1910 in Pamijahan. Most photos from the year 1925 (3 out of 4) showed additional roof. Those mosques were located in Tasikmalaya and Garut Regency. They were the Mosque in Singaparna, Cibatu, and Garut. The mosque with rather distinctive roof characteristics was Istri Mosque, because it was adorned with dome unlike any other mosques.

\section{Closing Remarks}

Based on the above analysis, the architectural characteristics of old mosques in Priangan can be concluded. Most of the mosques had symmetrical mass and only consisted of the main mass. Most of the mosques had transitional space that surrounded their main room or their mass. Most of the mosques also had 2 stacked pyramidal main roof form with 2 sloping angles.

Beside the general cases, there were also some unique characteristics of the mosques. The Mosque in Cibatu, Garut (1925), had rather distinctive mass due to its twin towers, which were usually presented on the great mosques in Priangan. The Mosque in Garut (1925) and Pamijahan, Tasikmalaya Regency (1910) were the rather distinctive mosques from the transitional space characteristics. The Msoque in Garut only had the transitional space in front of the main room, while the Mosque in Pamijahan had it in the form of trench-like space, different from any other mosques. But the most distinctive mosque of all was Istri Mosque in Pengkolan, Garut City (1925). The mosque had a dome, did not have any transitional space, and its symmetricity could not be determined due to it's photo angle. There were also some tendencies between neighboring regencies, which occured in Tasikmalaya and Garut. Both of them had mosques with additional masses and roofs.

There were some certain years of photo taking which showed certain transformation of the mosques characteristics. Photo in year 1910 showed the first mosque with mass and roof addition in Pamijahan. However, the photos from 1925, which contributed the largest number of photos, showed the peak of additional roof. Those photos also showed the most varied transitional space configurations.

There were also some events which took place in the Dutch East Indies during the year 1925. In 1924, the cities' state of gemeente (city with partial autonomy rights) was changed into stadsgemeente (city with full autonomy rights). In 1926, the Java Island was divided into 3 provinces, which were West Java, Central Java, and East Java ${ }^{10}$. Those administration reforms, which were the attempts toward decentralization, could have possibly made the responsible of the authorities to fell on smaller areas. Therefore, the fringes or inland areas would have had received more attention, such as perhaps some documentation efforts.

\section{References}

1 A. Sobana Hardjasaputra. 2004. Bupati di Priangan; Kedudukan dan Peranannya pada Abad ke-17 - Abad ke-19 dalam Bupati di Priangan; dan Kajian Lainnya mengenai Budaya Sunda. Bandung: Pusat Studi Sunda

2 Edi S. Ekadjati. 2005. Kebudayaan Sunda (Suatu Pendekatan Sejarah). Jilid I. Jakarta: PT Dunia Pustaka Jaya

3 Nina Herlina Lubis. 2000. Sumedang dalam Sejarah Kota-kota Lama di Jawa Barat. Bandung: Alqaprint

4 Thommy Svensson. 1991. State Bureaucracy and Capitalism in Rural West Java: Local Gentry versus Peasant Entepreneurs in Priangan in the 19th and 20th Century. Nias Report no. 1. Copenhagen: Nordic Institute of Asian Studies

5 Kunto Sofianto. 2001. Garoet Kota Intan: Sejarah Lokal Kota Garut Sejak Zaman Kolonial Belanda Hingga Masa Kemerdekaan. Sumedang: Alqaprint

6 Bambang Setia Budi. 2005. A Study on the History and Development of the Javanese Mosque, Part 2: The Historical Setting and Role of the Javanese Mosque under the Sultanates. Journal of Asian Architecture and Building Engineering. Volume 4(1)

7 Miftahul Falah. 2010. Sejarah Kota Tasikmalaya 1820 - 1942. Uga Tatar Sunda dan Yayasan Masyarakat Sejarawan Indonesia, Cabang Jawa Barat

8 Mahmood Ahmed Bakir Khayat dan Binyad Maruf Abdulkadir Khaznadar. 2010. Formal Characteristics of Vernacular Architecture in Erbil City and Other Iraqi Cities. The Iraqi Journal of Architecture. Volume 19-20-21

9 Bambang Setia Budi. 2004. A Study on the History and Development of the Javanese Mosque, Part 1: A Review of Theories on the Origin of the Javanese Mosque. Journal of Asian Architecture and Building Engineering. Volume 3(1)

10 Nina Herlina Lubis. 1998. Kehidupan Kaum Menak Priangan 1800 - 1942. Bandung: Pusat Informasi Kebudayaan Sunda 